\title{
Gastrointestinal tract carcinoma in pediatric and adolescent age: The Italian TREP project experience
}

\author{
Alice Indini ${ }^{1}$ (D) | Gianni Bisogno ${ }^{2}$ | Giovanni Cecchetto ${ }^{3}$ | Marco Vitellaro $^{4,5}$ | \\ Stefano Signoroni ${ }^{4}$ | Maura Massimino ${ }^{1}$ | Giovanna Riccipetitoni ${ }^{6}$ | Marco Zecca ${ }^{7}$ \\ Patrizia Dall'Igna $^{8}$ (D) | Maria Debora De Pasquale9 | Alessandro Inserra ${ }^{10}$ | \\ Stefano Chiaravalli ${ }^{1}$ | Eleonora Basso ${ }^{11}$ | Calogero Virgone ${ }^{3}$ | Silvia Sorbara ${ }^{2}$ | \\ Maria Di Bartolomeo $^{12}$ | Paolo D'Angelo ${ }^{13}$ (D) | Andrea Ferrari ${ }^{1}$ (iD

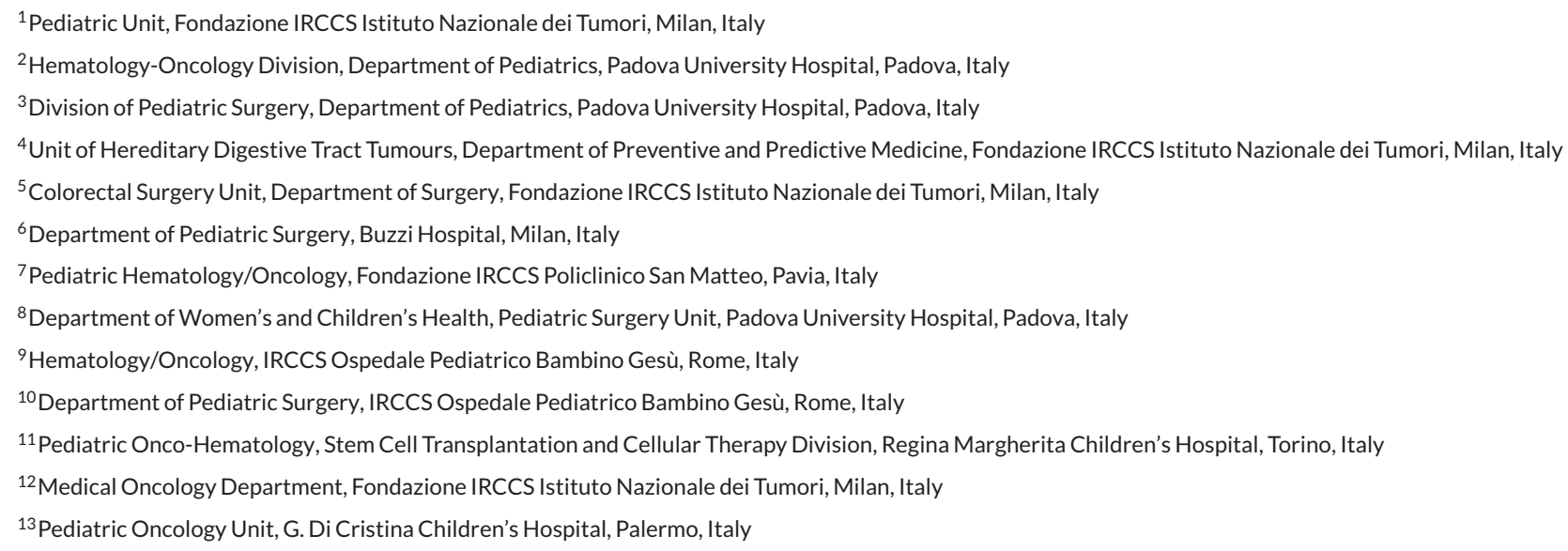

\section{Correspondence}

Alice Indini, Pediatric Unit, Fondazione IRCCS Istituto Nazionale dei Tumori,

Via Venezian 1, 20133 Milan, Italy.

Email:alice.indini@istitutotumori.mi.it

Funding information

Grant sponsor: "Fondazione Città della Speranza," Padova; Grant sponsor: "Fondazione

Cassa di Risparmio di Padova e Rovigo."

\begin{abstract}
Background: Gastrointestinal (GI) carcinomas are very rare in the pediatric and adolescent age range. We report the clinical features, treatment, and outcome of a series of children and adolescents with GI carcinoma prospectively registered in the Italian Tumori Rari in Età Pediatrica (TREP) project.
\end{abstract}

Methods: The TREP project developed diagnostic and therapeutic guidelines based on recommendations currently in use for adults. Clinical data were centrally registered and reviewed.

Results: Fifteen patients were registered over the years 2000-2016. Most of the tumors were colorectal carcinomas (12 cases). All but one patient had advanced-stage disease (American Joint Committee on Cancer stages III-IV), and the majority of patients had aggressive histological subtypes, i.e. poorly differentiated (G3) (five patients), mucinous (four patients), and signet ring (two patients) adenocarcinomas. Surgery was performed in 13 of 15 patients, and was radical in nine of 13 patients. Only one patient received postoperative radiotherapy. All patients received chemotherapy, with the addition of bevacizumab in two cases. Nine patients were still alive at the time of the present report, but two of them had only just completed their treatment program and one patient is still on treatment. Six patients died due to disease progression.

Conclusions: This prospective report on pediatric GI tract carcinomas confirms the rarity and biological aggressiveness of these diseases in pediatric and adolescent age. Further prospective

Abbreviations: AIRTum, Associazione Italiana Registro Tumori; AJCC, American Joint Committee on Cancer; CRC, colorectal carcinoma; FAP, familial adenomatous polyposis; GI, gastrointestinal; HDGC, hereditary diffuse gastric cancer; IHC, immunohistochemistry; LS, Lynch syndrome; MMR, mismatch repair; TNM, tumor node metastases; TREP, Tumori Rari in Età Pediatrica 
studies are needed to explore the distinct biology of tumor in this age group in order to find new therapeutic targeted agents.

KEYWORDS

adenocarcinoma, colorectal cancer, children, rare pediatric tumors, TREP

\section{1 | INTRODUCTION}

Gastrointestinal (GI) carcinomas are among the most common tumors of adulthood. ${ }^{1-4}$ Colorectal carcinoma (CRC) is the fourth most common cancer worldwide, ${ }^{1}$ accounting for $8 \%$ of all new cancers in the United States. In Italy, it is the third most common cancer, representing $13 \%$ of all new cancers. ${ }^{2}$ Gastric cancer is the fifth most frequently diagnosed cancer and the third leading cause of cancer-related death worldwide, with a higher incidence in Asian countries, South America, and Eastern Europe. ${ }^{3,4} \mathrm{Gl}$ carcinomas can occur as part of hereditary syndromes ${ }^{5}$ and may be associated, especially in young patients, with Lynch syndrome (LS), familial adenomatous polyposis (FAP), other forms of polyposis, ${ }^{6}$ and hereditary diffuse gastric cancer (HDGC) syndrome. ${ }^{7}$

GI carcinomas are extremely rare in pediatric and adolescent age: CRC accounts for $<0.1 \%$ of new tumors in patients $<15$ years old ${ }^{8}$ and primary gastric adenocarcinoma for only $0.05 \%$ of all pediatric GI malignancies. ${ }^{9}$ Over the past decades, considerable progress has been made in the management of colorectal cancer, leading to a significant improvement of overall survival. This has been attributed in part to aggressive surgical approaches and in part to our understanding of the disease's molecular biology and emergence of newer molecular targets. ${ }^{10}$ Such an improvement in survival has not been seen in pediatric age. The rare cases occurring in children and adolescents characteristically carry a poor prognosis, related mainly to late diagnosis and advanced stage at presentation, but also to biological aggressiveness (i.e., high-grade disease and poorly differentiated, signet ring or mucinous adenocarcinoma histologies with a higher incidence of microsatellite instability ${ }^{11}$ ).

There are relatively few reports in the literature on these tumors, and pediatric oncologists and surgeons have little experience of managing these patients. To offer clinical support for physicians encountering such uncommon cases, the Tumori Rari in Età Pediatrica (TREP, rare tumors in pediatric age) project was set up in 2000 in Italy for the purpose of collecting epidemiological data and developing diagnostic and therapeutic guidelines for the management of rare pediatric tumors (i.e., pediatric solid malignancies with an annual incidence $<2 /$ million), so that pediatric oncologists and surgeons can cooperate with experts in adult oncology in the management of such "orphan" diseases. ${ }^{12}$

This article reports the clinical details on a series of children and adolescents with GI tract (colorectal, small bowel, stomach) carcinomas prospectively collected in the TREP database.

\section{2 | MATERIALS AND METHODS}

Patients $\leq 18$ years old diagnosed with $\mathrm{Gl}$ tract carcinomas were registered centrally as of September 1,2000 by the TREP Data Center
(Clinical Trials and Biostatistics Unit, Istituto Oncologico Veneto, Padova, Italy) using dedicated forms to record epidemiological details, clinical findings, diagnostic and therapeutic work-up, and follow-up. All patients, or their legal guardians, gave their informed consent to their involvement in the TREP study.

Patients' clinical details were reviewed for the present report. Definition of family cancer history was intended according to Amsterdam criteria and Bethesda Guidelines. ${ }^{13}$ Histological diagnoses were obtained by one of the pathologists on the TREP panel and/or were centrally confirmed by the panel. For histotyping and grading, reference was made to the World Health Organization Classification of Tumors of the Digestive System (third edition for tumors diagnosed up to 2010 , and fourth edition for tumors diagnosed afterward). Disease staging was done according to the tumor node metastases (TNM) staging system of the American Joint Committee on Cancer (AJCC), sixth edition, ${ }^{14}$ based on the level of invasion of the primary tumor (mucosa, submucosa, muscularis propria, serosa, or beyond) and the number of nodes involved.

The number of patients enrolled in the TREP database was compared with the number of cases of GI tract carcinoma expected to be diagnosed in patients $\leq 18$ years old in Italy according to the Associazione Italiana Registro Tumori (AIRTum), the Italian network of population-based cancer registries, which comprises 22 general registries and three specialist registries, and covers $33 \%$ of all Italian children. ${ }^{15}$

\section{3 | DIAGNOSTIC AND THERAPEUTIC GUIDELINES}

The TREP diagnostic guidelines recommend abdominal ultrasound and gastro- or colonoscopy (with or without biopsy) as first-level investigations. Patients with predisposing genetic syndromes also undergo wireless capsule endoscopy. ${ }^{16}$ Disease staging requires computed tomography of the chest and abdomen, and positron emission tomography for the detection of metastases and disease recurrence. Plasma levels of carcinoembryonic antigen and carbohydrate antigen 19.9 are tested as markers of disease at diagnosis (especially for adenocarcinoma), and are usually monitored to assess response to treatment in metastatic patients, or for the early detection of recurrent disease.

The TREP project recommendations for the treatment of GI carcinomas in pediatric age are much the same as for adult cases. ${ }^{17}$ Surgery is considered the mainstay of treatment for both localized and advanced disease, and it has to be timely and radical (often involving multivisceral resection and peritonectomy). Surgery is the only treatment for early-stage tumors (i.e., TNM stages T1-2, N0, M0), but is currently used in advanced-stage disease too, sometimes with a 
palliative intent (e.g., for colic or gastric bypass). For patients with advanced-stage disease (AJCC stages III and IV), the TREP project recommends systemic treatment with adjuvant chemotherapy based on a combination of 5-fluorouracil and folinic acid with or without oxaliplatin. Other drugs with a demonstrated efficacy in CRC in the metastatic setting (e.g., capecitabine and irinotecan) and novel target therapies (e.g., bevacizumab) have been used at the treating physician's discretion.

Postoperative radiotherapy has a definite role in rectal cancer (particularly when combined with 5FU-based chemotherapy), but is not standard for colon cancer, and is only used in some cases of gastric cancer. The TREP guidelines suggest surgical resection as the treatment of choice for hepatic metastases, although alternative local treatments (radiofrequency ablation, cryoablation, and chemoembolization) may be considered in selected cases.

\section{4 | RESULTS}

Table 1 shows the clinical characteristics, treatments, and outcomes of the patients collected in the present sample. Over the study period (September 2000-September 2016), 15 patients seen at six pediatric oncology centers were registered in the TREP database: most of them ( $n=12$ ) had CRC, two had small bowel cancer, and one had gastric carcinoma. Five cases with CRC have been already included in a previous report (single-institutional series from the Istituto Nazionale Tumori of Milan). ${ }^{18}$ Based on the AIRTum data, ${ }^{19}$ the annual number of cases of Gl tract carcinomas to be expected in Italy in the population aged 017 years is 1.75 . The annual number of cases actually registered in the TREP database was 0.93 , giving a ratio of observed-to-expected cases of 0.53 .

Patients' age at diagnosis ranged from 9 to 18 years, with a median of 15 years. Two patients had a family history of colorectal cancer. Moreover, three patients received immunohistochemistry (IHC) for mismatch repair (MMR) proteins and molecular analysis for microsatellite instability on tumor tissue. Two patients showed defective expression of MMR proteins ( $\mathrm{MSH} 2$ negative expression) and high microsatellite instability: one of them was tested for MMR genes constitutive mutations (MLH1, MSH2, MSH6), resulting negative; the other patient needed chemotherapy treatment to be started soon at diagnosis, making the test not reliable while on treatment, and rapidly progressed to death at the end of therapy. Patients presented with a history of symptoms lasting from 1 to 12 months (median 1 month) before their disease was diagnosed, and more than 3 months in five cases. The most common symptoms were anemia and abdominal pain. All patients with colorectal cancer had unifocal disease, without evidence of polyps and adenomas: the site of disease was the right colon in six cases, the transverse colon in one, the left colon in four, and the rectum in one patient. Two patients had small bowel cancer and one had a gastric tumor. The histological diagnoses were as follows: moderately differentiated adenocarcinoma in three cases, poorly differentiated adenocarcinoma in five cases, mucinous carcinoma in four cases, and signet ring carcinoma in two cases. One patient with a gastric tumor had a histological diagnosis of mixed (dispersed cell and tubular) adenocarcinoma. Six patients with CRC had AJCC stage II/III disease, while the other patients of the present series had metastatic disease (AJCC stage IV).

Thirteen patients were managed surgically (nine of 13 patients with RO surgery), one patient with CRC was treated with radiotherapy, and the patient with metastatic gastric adenocarcinoma had no local treatment. All patients were given chemotherapy using various regimens (one patient underwent neoadjuvant chemotherapy), and two CRC patients were treated with a combination of chemotherapy and bevacizumab.

At the time of the present report, nine patients were still alive, six of them with no evidence of disease, a mean 51.7 months (range 12129) since their diagnosis (while two of them had only just completed their planned treatment and one of them is still on treatment). Six patients experienced progressive disease, a mean 9.3 months (range 0-20) after completing their treatment, and died of their disease, a mean 17 months (range 3-34) after diagnosis. Figure 1 shows 2year disease free survival (DFS) and overall survival (OS) of these patients.

\section{5 | DISCUSSION}

This report describes a prospective nationwide cooperative series of GI tract carcinomas in the pediatric and adolescent age range. The main findings of this study confirm the rarity of these tumors, their usually advanced stage at diagnosis, and their poor prognosis when treated with the standard treatment commonly used in adult patients.

As shown in Supplementary Tables S1 and S2, this is the first prospective Italian cooperative study on GI carcinomas. All the previous studies on $\mathrm{Gl}$ tract carcinomas in young people in the last 30 years ${ }^{6,18,20-56}$ were retrospective single-institution series concerning only a handful of cases seen over broad periods of time, and most of them concerned patients $\leq 30$ years of age. The only reports with a more substantial body of data are those published by tumor registries (e.g., Surveillance, Epidemiology and End Results). The main findings emerging from these records are the features of this disease in pediatric age (i.e., aggressive histology, advanced stage), the importance of early diagnosis and radical surgery, and the overall poor prognosis except for a slight better outcome for tumors arising in the context of cancer predisposition syndromes.

Since GI carcinomas are so uncommon in pediatric age, a centralized case collection and a cooperative approach are needed in order to develop practical guidelines for their diagnosis and treatment, and to offer an advisory service for physicians encountering such patients in their clinical practice. The TREP project is a cooperative network of pediatric care centers and this study shows that national multicenter prospective studies are feasible even for such rare diseases.

Based on the TREP guidelines, patients in the present series were managed homogeneously according to shared procedures concerning diagnosis, surgery, and other treatments. Patient management was the result of a cooperation between pediatric oncologists and surgeons, combined with the advice of adult oncologists and geneticists. 
TABLE 1 Patients' characteristics

\begin{tabular}{|c|c|c|c|c|c|c|c|c|c|}
\hline Patient, n & $\begin{array}{l}\text { Sex, age } \\
\text { (years) }\end{array}$ & $\begin{array}{l}\text { Family } \\
\text { history }\end{array}$ & $\begin{array}{l}\text { Symptoms } \\
\text { (duration) }\end{array}$ & Site & Histology & Local treatment & Stage & Therapy & Outcome \\
\hline 1 & $\begin{array}{l}\text { Female, } \\
12\end{array}$ & Yes & $\begin{array}{l}\text { Anemia, weight } \\
\text { loss (5 } \\
\text { months) }\end{array}$ & Left colon & $\begin{array}{l}\text { Poorly } \\
\text { differentiated } \\
\text { adenocarcinoma }\end{array}$ & $\begin{array}{l}\text { Left hemicolectomy } \\
\text { RO }\end{array}$ & $\begin{array}{l}\text { T3N2MO } \\
\text { stage IIllc }\end{array}$ & $\begin{array}{l}\text { 5FU-FA } \\
\quad \text { for } 12 \text { cycles }\end{array}$ & $\begin{array}{l}\text { Abdominal } \\
\text { progression at } 14 \\
\text { months, DOD at } 26 \\
\text { months }\end{array}$ \\
\hline 2 & $\begin{array}{c}\text { Male, } \\
18\end{array}$ & No & Unknown & $\begin{array}{l}\text { Right colon } \\
\quad \text { (ileocecal } \\
\text { valve) }\end{array}$ & $\begin{array}{l}\text { Mucinous } \\
\text { adenocarcinoma }\end{array}$ & $\begin{array}{l}\text { Right hemicolectomy } \\
\text { RO }\end{array}$ & $\begin{array}{l}\text { T4N2MO } \\
\text { stage IIllc }\end{array}$ & $\begin{array}{l}\text { OXA-Xeloda } \\
\text { for six cycles }\end{array}$ & $\begin{array}{l}\text { Local relapse at } 20 \\
\text { months, DOD at } 34 \\
\text { months }\end{array}$ \\
\hline 3 & $\begin{array}{c}\text { Female, } \\
13\end{array}$ & No & $\begin{array}{l}\text { Anemia, } \\
\text { abdominal } \\
\text { mass ( } 2 \\
\text { months) }\end{array}$ & Right colon & $\begin{array}{l}\text { Mucinous } \\
\text { adenocarcinoma }\end{array}$ & $\begin{array}{l}\text { Palliative colic by-pass } \\
\text { and biopsy } \\
\text { R2 }\end{array}$ & $\begin{array}{l}\text { T4N2M1a } \\
\text { (peritoneal } \\
\text { carcinosis) } \\
\text { stage IV }\end{array}$ & $\begin{array}{l}\text { CPT11-Xeloda } \\
\text { for four cycles }\end{array}$ & $\begin{array}{l}\text { Abdominal } \\
\text { progression at } 4 \\
\text { months, DOD at } 10 \\
\text { months }\end{array}$ \\
\hline 4 & $\begin{array}{c}\text { Male, } \\
13\end{array}$ & No & Pain (1 month) & Sigmoid colon & $\begin{array}{l}\text { Moderately } \\
\text { differentiated } \\
\text { adenocarcinoma }\end{array}$ & $\begin{array}{l}\text { Left hemicolectomy } \\
\text { R2 }\end{array}$ & $\begin{array}{l}\text { T4N2M1a } \\
\text { (peritoneal } \\
\text { carcinosis) } \\
\text { stage IV }\end{array}$ & $\begin{array}{l}\text { CPT11-OXA-Xeloda } \\
\text { for six cycles }\end{array}$ & $\begin{array}{l}\text { Abdominal } \\
\text { progression at } 6 \\
\text { months, DOD at } 17 \\
\text { months }\end{array}$ \\
\hline 5 & $\begin{array}{c}\text { Male, } \\
9\end{array}$ & No & $\begin{array}{l}\text { Proctorrhagia, } \\
\text { anemia (12 } \\
\text { months) }\end{array}$ & Sigmoid colon & $\begin{array}{l}\text { Mucinous } \\
\text { adenocarcinoma }\end{array}$ & $\begin{array}{l}\text { Rectum-sigmoid } \\
\text { resection } \\
\text { RO }\end{array}$ & $\begin{array}{l}\text { T3NOMO } \\
\text { stage Ila }\end{array}$ & $\begin{array}{l}\text { FOLFOX } \\
\text { for } 12 \text { cycles }\end{array}$ & $\begin{array}{l}\text { Alive without evidence } \\
\text { of disease } 129 \\
\text { months after } \\
\text { diagnosis }\end{array}$ \\
\hline 6 & $\begin{array}{c}\text { Male, } \\
15\end{array}$ & No & $\begin{array}{c}\text { Anemia (1 } \\
\text { month) }\end{array}$ & right colon & $\begin{array}{l}\text { Poorly } \\
\text { differentiated } \\
\text { adenocarcinoma }\end{array}$ & $\begin{array}{l}\text { Right hemicolectomy } \\
\text { RO }\end{array}$ & $\begin{array}{l}\text { pT3 } \\
\text { pN2bM0 } \\
\text { stage IIlb }\end{array}$ & $\begin{array}{l}\text { FOLFOX } \\
\text { for } 12 \text { cycles }\end{array}$ & $\begin{array}{l}\text { Alive without evidence } \\
\text { of disease } 12 \\
\text { months after } \\
\text { diagnosis }\end{array}$ \\
\hline 7 & $\begin{array}{c}\text { Male, } \\
16\end{array}$ & No & $\begin{array}{l}\text { Intestinal } \\
\text { occlusion (1 } \\
\text { month) }\end{array}$ & $\begin{array}{l}\text { Transverse } \\
\text { colon }\end{array}$ & $\begin{array}{l}\text { Signet ring } \\
\quad \text { carcinoma G3 }\end{array}$ & $\begin{array}{l}\text { Hemicolectomy } \\
\text { R1 }\end{array}$ & $\begin{array}{l}\text { pT4 pN2bpM1a } \\
\text { (peritoneal } \\
\text { carcinosis) } \\
\text { stage IV }\end{array}$ & $\begin{array}{l}\text { FOLFOX } \\
\quad \text { for } 12 \text { cycles }\end{array}$ & $\begin{array}{l}\text { Alive with no evidence } \\
\text { of disease (just } \\
\text { completed tumor } \\
\text { treatment) }\end{array}$ \\
\hline 8 & $\begin{array}{l}\text { Female, } \\
15\end{array}$ & Yes & $\begin{array}{l}\text { Proctorrhagia } \\
\text { (1 month) }\end{array}$ & Rectum & $\begin{array}{l}\text { Poorly } \\
\text { differentiated } \\
\text { adenocarcinoma }\end{array}$ & $\begin{array}{l}\text { Rectum resection } \\
\text { RO }\end{array}$ & $\begin{array}{l}\text { pT3N1M0 } \\
\text { stage IIIb }\end{array}$ & $\begin{array}{l}\text { FOLFOX for } 12 \\
\text { cycles } \\
\text { Radiotherapy }\end{array}$ & $\begin{array}{l}\text { Alive without evidence } \\
\text { of disease } 32 \\
\text { months after } \\
\text { diagnosis }\end{array}$ \\
\hline 9 & $\begin{array}{l}\text { Female, } \\
15\end{array}$ & No & $\begin{array}{l}\text { Pain, stipsis (6 } \\
\text { months) }\end{array}$ & Left colon & $\begin{array}{l}\text { Poorly } \\
\text { differentiated } \\
\text { adenocarcinoma }\end{array}$ & $\begin{array}{l}\text { Palliative colic bypass } \\
\text { and biopsy } \\
\text { R2 }\end{array}$ & $\begin{array}{l}\text { T4N2M1a } \\
\text { (peritoneal } \\
\text { carcinosis) } \\
\text { stage IV }\end{array}$ & $\begin{array}{l}\text { FOLFIRI for } 12 \\
\text { cycles }\end{array}$ & DOD at 12 months \\
\hline 10 & $\begin{array}{l}\text { Female, } \\
15\end{array}$ & No & $\begin{array}{l}\text { Pain } \\
\text { (1 month) }\end{array}$ & Right colon & $\begin{array}{l}\text { Poorly } \\
\text { differentiated } \\
\text { adenocarcinoma } \\
\text { (signet ring) }\end{array}$ & $\begin{array}{l}\text { Right hemicolectomy } \\
\text { RO }\end{array}$ & $\begin{array}{l}\text { T4N2MO } \\
\text { stage IIllc }\end{array}$ & $\begin{array}{l}\text { FOLFOX } \\
\text { for } 12 \text { cycles }\end{array}$ & $\begin{array}{l}\text { Alive without evidence } \\
\text { of disease } 38 \\
\text { months after } \\
\text { diagnosis }\end{array}$ \\
\hline 11 & $\begin{array}{c}\text { Male, } \\
15\end{array}$ & No & $\begin{array}{l}\text { Pain, anemia, } \\
\text { fever (1 } \\
\text { month) }\end{array}$ & $\begin{array}{l}\text { Cecum, right } \\
\text { colon }\end{array}$ & Adenocarcinoma G2 & Radiotherapy & $\begin{array}{l}\text { T2N1M1 } \\
\text { (liver) } \\
\text { stage IV }\end{array}$ & $\begin{array}{l}\text { FOLFOXIRI- } \\
\text { bevacizumab } \\
\text { for four cycles } \\
\text { and FOLFOXIRI } \\
\text { for two cycles }\end{array}$ & $\begin{array}{l}\text { Alive with no evidence } \\
\text { of disease (just } \\
\text { completed tumor } \\
\text { treatment) }\end{array}$ \\
\hline 12 & $\begin{array}{l}\text { Female, } \\
12\end{array}$ & No & $\begin{array}{l}\text { Proctorrhagia, } \\
\text { weight loss, } \\
\text { abdominal } \\
\text { pain, anemia } \\
\text { (1 month) }\end{array}$ & Right colon & $\begin{array}{l}\text { Poorly } \\
\text { differentiated } \\
\text { adenocarcinoma }\end{array}$ & $\begin{array}{l}\text { Right hemicolectomy } \\
\text { RO and extensive } \\
\text { lymphadenectomy }\end{array}$ & $\begin{array}{l}\text { pT3N1M1 } \\
\text { (liver) } \\
\text { stage IV }\end{array}$ & $\begin{array}{l}\text { FOLFOXIRI for two } \\
\text { cycles as } \\
\text { preoperative } \\
\text { treatment }\end{array}$ & $\begin{array}{l}\text { Too early to say } \\
\text { (patient still on } \\
\text { treatment) }\end{array}$ \\
\hline 13 & $\begin{array}{c}\text { Male, } \\
17\end{array}$ & Unknown & Intussusception & Small bowel & $\begin{array}{l}\text { Mucinous } \\
\text { adenocarcinoma }\end{array}$ & $\begin{array}{l}\text { Ileal resection } \\
\text { RO }\end{array}$ & $\begin{array}{l}\text { T3N1M0 } \\
\text { stage IIlb }\end{array}$ & $\begin{array}{l}\text { FOLFOX for } 12 \\
\text { cycles }\end{array}$ & $\begin{array}{l}\text { Alive without evidence } \\
\text { of disease } 34 \\
\text { months after } \\
\text { diagnosis }\end{array}$ \\
\hline 14 & $\begin{array}{c}\text { Male, } \\
17\end{array}$ & No & $\begin{array}{c}\text { Anemia (11 } \\
\text { month) }\end{array}$ & Small bowel & Adenocarcinoma G2 & $\begin{array}{l}\text { Ileal resection } \\
\text { RO }\end{array}$ & $\begin{array}{l}\text { pT3pN1pM0 } \\
\text { stage IIllb }\end{array}$ & $\begin{array}{l}\text { FOLFOX- } \\
\text { bevacizumab } \\
\text { for } 12 \text { cycles }\end{array}$ & $\begin{array}{l}\text { Alive without evidence } \\
\text { of disease } 65 \\
\text { months after } \\
\text { diagnosis }\end{array}$ \\
\hline 15 & $\begin{array}{l}\text { Female, } \\
16\end{array}$ & No & $\begin{array}{l}\text { Weight loss, } \\
\text { pain, anemia } \\
\text { supraclavear } \\
\text { mass (3 } \\
\text { months) }\end{array}$ & Stomach & $\begin{array}{l}\text { Mixed (dispersed } \\
\text { cell and tubular) } \\
\text { adenocarcinoma } \\
\text { G3 }\end{array}$ & biopsy & $\begin{array}{l}\text { pT1aN3M1 } \\
\text { (extraregional } \\
\text { nodes, lung) } \\
\text { stage IV }\end{array}$ & $\begin{array}{l}\text { EOC } \\
\text { for three cycles }\end{array}$ & $\begin{array}{l}\text { DOD before end of } \\
\text { treatment }\end{array}$ \\
\hline
\end{tabular}

5FU, 5'fluorouracil; CPT11, irinotecan; EOC, epirubicin-oxaliplatin-capecitabine; FA, folinic acid; FOLFOX, 5FU-FA-OXA; FOLFIRI, 5FU-FA-CPT11; FOLFOXIRI, 5FU-FA-OXA-CPT11; OXA, oxaliplatin. 

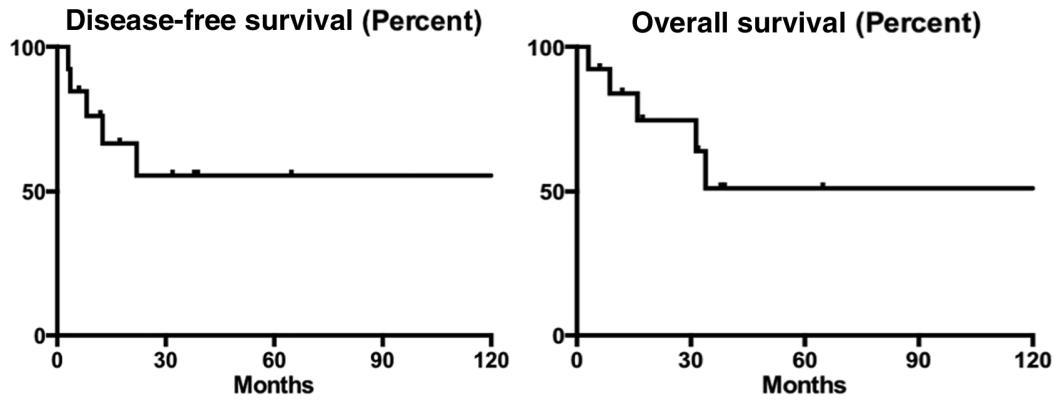

FIGURE 1 Two-year DFS and OS of patients in the present series

Despite the limited number of cases in our series (due to the rarity of these tumors), some conclusions can be drawn about the clinical history of GI tract carcinomas in pediatric age. First, our series confirms that these cancers are very rare in young people. Over a study period of 16 years (from 2000 to 2016), only 15 cases were collected in patients $\leq 18$ years old, and none were less than 9 years old. Second, all the patients in this series had advanced-stage disease (stages III-IV) with aggressive biological features (poorly differentiated, mucinous, and signet ring adenocarcinomas). The relatively high number of patients still alive after disease diagnosis in this series is mainly due to the fact that two of them had just completed their cancer treatment and one patient was still on treatment at the time of the present report. As seen in previous studies, ${ }^{35,38,42,44,49}$ patients with more extensive disease (stages IIIC-IV) usually had a worse prognosis, with early tumor relapse or progression after treatment.

The poor prognosis for $\mathrm{GI}$ tract carcinomas in pediatric age is largely related to the high incidence of aggressive histotypes, but other factors contribute to this issue. ${ }^{57}$ For a start, there is the difficulty of arriving at an early diagnosis of sporadic tumors in this time of life. This may be partly because of the unspecific presenting symptoms of GI cancers, but also due to a scarce awareness of the possibility of these diseases arising in pediatric age. At disease onset, the most common features are similar to those reported in adult patients and mainly involve local signs (changes in bowel habits, rectal tenesmus, reduction in stool diameter, bleeding or increase in mucus, abdominal pain), or constitutional symptoms (weight loss). Advanced cases may present with intestinal obstruction. Iron-deficiency anemia might be the presenting sign in cases of chronic occult bleeding. Patients diagnosed with genetic syndromes that predispose them to GI malignancy undergo routine endoscopic screening starting from around the age of 10-14 years. ${ }^{16,58,59}$

Another feature with a potentially negative influence on survival in children and adolescents might be pediatric specialists' scant experience of managing $\mathrm{Gl}$ cancer. This is certainly not easy to demonstrate or quantify, but various studies in the adult setting have shown that patients who receive appropriate surgical treatment have a better prognosis than patients who do not, ${ }^{45}$ and suggested that patient outcomes are influenced by the experience of treating centers.

One might speculate that $\mathrm{Gl}$ carcinomas developing in pediatric age have a different pathogenesis and more aggressive biological features, and this would explain the disease's rapid dissemination even in the absence of symptoms. Looking at the model of adult colorectal carcinogenesis, cell transformation is the result of a slow, multistep process comprising a large number of genetic changes that jointly contribute to the acquisition of an invasive phenotype. ${ }^{60}$ Gastric carcinoma also derives from exposure to various environmental factors, such as Helicobacter pylori infection, smoking, heavy alcohol drinking, and other dietary factors. ${ }^{61}$ The epithelial transformation process in pediatric age can hardly have the same time dependence (age-related cell degeneration), or association with environmental exposure to carcinogens, and this makes us wonder how it can happen in the absence of predisposing syndromes. Young age at the onset of malignancy is frequently associated with specific mutations of genes involved in cell transformation and proliferation (e.g., mutation of the adenomatous polyposis coli gene related to FAP; pathogenic variants in MMR genes, related to LS; germline mutations in $\mathrm{CDH} 1$ [E-cadherin] predisposing to HDGC). Such patients are managed with genetic counseling, intensive surveillance from an early age to arrive at a prompt diagnosis. Prophylactic colectomy is recommended to prevent the early onset of CRC in FAP patients. ${ }^{62-64}$ Laparoscopic approach has been reported to have acceptable short- and long-term postsurgical and oncological outcomes: for adolescents this can support the decision making for prophylactic surgery in FAP patients reducing the risk of cancer. ${ }^{65}$ In LS, usually a segmental resection is performed, and the genetic mutation is identified after the primary surgery. In LS, the risk of developing a second CRC after segmental resection for primary CRC has been reported to be approximately $16 \%$ at 10 years follow-up despite close surveillance. ${ }^{66}$ In view of this risk, more extensive treatment of the primary CRC might be considered, especially in young patients.

In the present series, only two patients had a family history of CRC, and none of them had been diagnosed with a hereditary syndrome. An important limitation of our report concerns the lack of immunohistochemical and molecular analyses conducted on tumor tissues. A further study is underway in cooperation with geneticists, pathologists, and adult oncologists to apply molecular sequencing to examine the tumor tissues of all the patients included in the present series and compare them with the features seen in adult cases.

In the future TREP recommendations, molecular analysis of tumor tissue (by means of IHC for MMR gene proteins, analysis of micro satellite instability (MSI) status, and potentially next-generation sequencing techniques) and determination of peculiar hallmarks (e.g., Epstein Barr virus and $H$. pylori expression in gastric cancer), together with screening for cancer predisposition syndromes, will be considered (also through multigene panel testing) in order to better characterize 
disease features in this subset of patients and possibly guide the choice for more tailored treatments.

To sum up, this is the first national cooperative prospective study on GI tract carcinomas occurring in pediatric and adolescent age. Our results confirm the rarity and biological aggressiveness of this disease in this age group, which often carries a very poor prognosis. Radical surgery is the mainstay of treatment and is usually feasible in cases of limited disease, which means that early diagnosis is fundamentally important. The treatment of these cancers in pediatric age is still largely extrapolated from experience with adults and suspected cases should be referred to oncology centers with links to experts dedicated to the management of this disease in adults. In the last years, a growing knowledge of the molecular changes that occur in the adult disease has enabled the development of specific targeted therapies for use in combination with chemotherapy to gain a better disease control rate. Characterizing the corresponding molecular changes in the pediatric disease with the aid of IHC, specific molecular analyses, and next-generation sequencing techniques, together with the detailed study of family histories and any further genetic insights, will help to broaden our understanding of this disease and hopefully lead to new therapeutic options in this setting. Finally, our nationwide experience highlights the need of broad-based international prospective cooperation. Together with other groups, the TREP project have founded the European Cooperative Study Group for Pediatric Rare Tumors (EXPeRT), with the primary aim of promoting international clinical and biological research on very rare pediatric tumors. ${ }^{67}$ After its foundation, EXPeRT has been able to find support to its activities in two projects funded by the European Union, that is, the European Expert Pediatric Oncology Reference Network for Diagnostics and Treatment (ExPO-r-Net) ${ }^{68}$ and the Joint Actions on Rare Cancers (JARC).

\section{ACKNOWLEDGMENTS}

The TREP project was partially supported by grants from the "Fondazione Città della Speranza," Padova, and the "Fondazione Cassa di Risparmio di Padova e Rovigo".

\section{CONFLICT OF INTEREST}

The authors declare that there is no conflict of interest.

\section{REFERENCES}

1. Siegel RL, Miller KD, Jemal A. Cancer statistics. CA Cancer J Clin. 2015;65:5-29.

2. AIRTUM Working Group. Italian cancer figures, report 2012: cancer in children and adolescents. Epidemiol Prev. 2013;37:1-225.

3. Ferlay J, Soerjomataram I, Dikshit R, et al. Cancer incidence and mortality worldwide: sources, methods and major patterns in GLOBOCAN 2012. Int J Cancer. 2015;136:E359-E386.

4. Corley DA, Buffler PA. Oesophageal and gastric cardia adenocarcinomas: analysis of regional variation using the Cancer Incidence in Five Continents database. Int J Epidemiol. 2001;30:1415-1425.

5. Bertario L, Signoroni S. Gastrointestinal cancer predisposition syndromes. In Rare Tumors in Children and Adolescents. Schneider D, Brecht I, Olson TA, Ferrari A, eds. Berlin/Heidelberg: Springer-Verlag; 2012.
6. Weber ML, Schneider DT, Offenmuller S, et al. Pediatric colorectal carcinoma is associated with excellent outcome in the context of cancer predisposition syndromes. Pediatr Blood Cancer. 2016;63:611617.

7. Hansford S, Kaurah P, Li-Chang $\mathrm{H}$, et al. Hereditary diffuse gastric cancer syndrome: CSH1 mutations and beyond. JAMA Oncol. 2015;1(1):23-32.

8. Howlader NA, Krapcho M, Miller D, et al. SEER Cancer Statistics Review, 1975-2013. National Cancer Institute. Bethesda, MD, https://doi.org/seer.cancer.gov/csr/1975_2013/, based on November 2015 SEER data submission, posted to the SEER web site, April 2016.

9. McGill TW, Downey EC, Westbrook J, Wade D, de la Garza J. Gastric carcinoma in children. J Pediatr Surg. 1993;28:1620-1621.

10. Van Cutsem E, Cervantes A, Nordlinger B, Arnold D. ESMO Guidelines Working Group. Metastatic colorectal cancer: ESMO Clinical Practice Guidelines for diagnosis, treatment and follow-up. Ann Oncol. 2014;25(Suppl 3):iii1-iii9.

11. Kim HC, Kim CN, Yu CS, Roh SA, Kim JC. Methylation of the hMLH1 and hMSH2 promoter in early-onset sporadic colorectal carcinomas with microsatellite instability. Int J Colorectal Dis. 2003;18:196-202.

12. Ferrari A, Bisogno G, De Salvo GL, et al. The challenge of very rare tumours in childhood: the Italian TREP project. Eur $J$ Cancer. 2007;43:654-659.

13. Vasen HF, Blanco I, Aktan-Collan K, et al. Revised guidelines for the clinical management of Lynch syndrome (HNPCC): recommendations by a group of European experts. Gut. 2013; 62(6):812-823.

14. Greene FL, American Joint Committee on Cancer. AJCC Cancer Staging Manual. New York: Springer, 2002.

15. Crocetti E, Airtum Working Group. [Numbers. Cancer survival in Italy is within the European average]. Epidemiol Prev. 2008;32:265.

16. Cavallo D, Ballardini G, Ferrari A, et al. Wireless capsule endoscopy in adolescents with familial adenomatous polyposis. Tumori. 2016;102:40-44.

17. Harting MT, Blakely ML, Herzog CE, Lally KP, Ajani JA, Andrassy RJ. Treatment issues in pediatric gastric adenocarcinoma. J Pediatr Surg. 2004;39:e8-e10.

18. Ferrari A, Rognone A, Casanova M, et al. Colorectal carcinoma in children and adolescents: the experience of the Istituto Nazionale Tumori of Milan, Italy. Pediatr Blood Cancer. 2008;50:588-593.

19. Pastore G, De Salvo GL, Bisogno G, et al. Evaluating access to pediatric cancer care centers of children and adolescents with rare tumors in Italy: the TREP project. Pediatr Blood Cancer. 2009;53:152-155.

20. Rao BN, Pratt CB, Fleming ID, Dilawari RA, Green AA, Austin BA. Colon carcinoma in children and adolescents. A review of 30 cases. Cancer. 1985;55:1322-1326.

21. Lamego CM, Torloni H. Colorectal adenocarcinoma in childhood and adolescent. Report of 11 cases and review of the literature. Pediatr Radiol. 1989;19:504-508.

22. Taguchi T, Suita S, Hirata Y, Ishii E, Ueda K. Carcinoma of the colon in children: a case report and review of 41 Japanese cases. J Pediatr Gastroenterol Nutr. 1991;12:394-399.

23. LaQuaglia MP, Heller G, Filippa DA, et al. Prognostic factors and outcome in patients 21 years and under with colorectal carcinoma. J Pediatr Surg. 1992;27:1085-1089; discussion 9-90.

24. Brown RA, Rode H, Millar AJ, Sinclair-Smith C, Cywes S. Colorectal carcinoma in children. J Pediatr Surg. 1992;27:919-921.

25. Cozart DT, Lang NP, Hauer-Jensen M. Colorectal cancer in patients under 30 years of age. Contributors to the Southwestern Surgical Congress Unusual Case Registry. Am J Surg. 1993;166:764-767. 
26. Rodriguez-Bigas MA, Mahoney MC, Weber TK, Petrelli NJ. Colorectal cancer in patients aged 30 years or younger. Surg Oncol. 1996;5:189194.

27. Shahrudin MD, Noori SM. Cancer of the colon and rectum in the first three decades of life. Hepatogastroenterology. 1997;44:441-444.

28. Sebbag G, Lantsberg L, Arish A, Levi I, Hoda J. Colon carcinoma in the adolescent. Pediatr Surg Int. 1997;12:446-448.

29. Chung YF, Eu KW, Machin D, et al. Young age is not a poor prognostic marker in colorectal cancer. Br J Surg. 1998;85:1255-1259.

30. Karnak I, Ciftci AO, Senocak ME, Buyukpamukcu N. Colorectal carcinoma in children. J Pediatr Surg. 1999;34:1499-1504.

31. Pratt CB, Rao BN, Merchant TE, et al. Treatment of colorectal carcinoma in adolescents and young adults with surgery, 5-fluorouracil/leucovorin/interferon-alpha 2a and radiation therapy. Med Pediatr Oncol. 1999;32:459-460.

32. Bhatia S, Pratt CB, Sharp GB, Robison LL. Family history of cancer in children and young adults with colorectal cancer. Med Pediatr Oncol. 1999;33:470-475.

33. Sule AZ, Mandong BM. Malignant colorectal tumours in patients 30 years and below: a review of 35 cases. Cent Afr J Med. 1999;45:209212.

34. Vastyan AM, Walker J, Pinter AB, Gerrard M, Kajtar P. Colorectal carcinoma in children and adolescents-a report of seven cases. Eur J Pediatr Surg. 2001;11:338-341.

35. Chen LK, Hwang SJ, Li AF, Lin JK, Wu TC. Colorectal cancer in patients 20 years old or less in Taiwan. South Med J. 2001;94:1202-1205.

36. Stones DK, McGill N. Colon carcinoma in African children. Med Pediatr Oncol. 2003;40:410-411.

37. Radhakrishnan CN, Bruce J. Colorectal cancers in children without any predisposing factors. A report of eight cases and review of the literature. Eur J Pediatr Surg. 2003;13:66-68.

38. Durno C, Aronson M, Bapat B, Cohen Z, Gallinger S. Family history and molecular features of children, adolescents, and young adults with colorectal carcinoma. Gut. 2005;54:1146-1150.

39. Chantada GL, Perelli VB, Lombardi MG, et al. Colorectal carcinoma in children, adolescents, and young adults. J Pediatr Hematol Oncol. 2005;27:39-41.

40. Ladd AP, Grosfeld JL. Gastrointestinal tumors in children and adolescents. Semin Pediatr Surg. 2006;15:37-47.

41. Kravarusic D, Feigin E, Dlugy E, et al. Colorectal carcinoma in childhood: a retrospective multicenter study. J Pediatr Gastroenterol Nutr. 2007;44:209-211.

42. Hill DA, Furman WL, Billups CA, et al. Colorectal carcinoma in childhood and adolescence: a clinicopathologic review. J Clin Oncol. 2007;25:5808-5814.

43. Salas-Valverde S, Lizano A, Gamboa Y, et al. Colon carcinoma in children and adolescents: prognostic factors and outcome-a review of 11 cases. Pediatr Surg Int. 2009;25:1073-1706.

44. Sultan I, Rodriguez-Galindo C, El-Taani H, et al. Distinct features of colorectal cancer in children and adolescents: a population-based study of 159 cases. Cancer. 2010;116:758-765.

45. Singer G, Hoellwarth ME. Colorectal carcinomas in children: an institutional experience. Pediatr Surg Int. 2012;28:591-595.

46. Kim G, Baik SH, Lee KY, et al. Colon carcinoma in childhood: review of the literature with four case reports. Int J Colorectal Dis. 2013;28:157164.

47. Kaplan MA, Isikdogan A, Gumus M, et al. Childhood, adolescents, and young adults $(</=25 \mathrm{y}$ ) colorectal cancer: study of Anatolian Society of Medical Oncology. J Pediatr Hematol Oncol. 2013;35:83-89.
48. Al-Tonbary Y, Darwish A, El-Hussein A, Fouda A. Adenocarcinoma of the colon in children: case series and minireview of the literature. Hematol Oncol Stem Cell Ther. 2013;6: 29-33.

49. Rahman MA, Chowdhury TK, Bhuiyan MA, Al Farooq MA, Sajid MM, Banu T. Colorectal carcinoma in first decade of life: our experience. Pediatr Surg Int. 2014;30:847-851.

50. Poles GC, Clark DE, Mayo SW, et al. Colorectal carcinoma in pediatric patients: A comparison with adult tumors, treatment and outcomes from the National Cancer Database. J Pediatr Surg. 2016;51:10611066.

51. Curtis JL, Burns RC, Wang L, Mahour GH, Ford HR. Primary gastric tumors of infancy and childhood: 54-year experience at a single institution. J Pediatr Surg. 2008;43:1487-1493.

52. Sasaki H, Sasano H, Ohi R, et al. Adenocarcinoma at the esophageal gastric junction arising in an 11-year-old girl. Pathol Int. 1999;49:1109-1113

53. Windham TC, Termuhlen PM, Ajani JA, Mansfield PF. Adenocarcinoma of the stomach in patients age 35 years and younger: no impact of early diagnosis on survival outcome. J Surg Oncol. 2002;81:118-124; discussion 24-25.

54. Zhuge Y, Cheung MC, Yang R, Eldick D, Koniaris LG, Sola JE. Pediatric intestinal foregut and small bowel solid tumors: a review of 105 cases. J Surg Res. 2009;156:95-102

55. Lu J, Huang CM, Zheng $\mathrm{CH}$, et al. [Gastric carcinoma in a 12-year-old girl: a case report and literature review]. Zhonghua Wei Chang Wai Ke Za Zhi. 2012;15:967-970.

56. Zheng N, Xiao XM, Dong KR, Chen L, Ma YY, Li K. Primary gastric tumors in infants and children: 15 cases of 20-year report. J Cancer Res Clin Oncol. 2016;142:1061-1067.

57. da Costa Vieira RA, Tramonte MS, Lopes LF. Colorectal carcinoma in the first decade of life: a systematic review. Int J Colorectal Dis. 2015:30:1001-1006.

58. Winawer S, Fletcher R, Rex D, et al. Colorectal cancer screening and surveillance: clinical guidelines and rationale-update based on new evidence. Gastroenterology. 2003;124:544-560.

59. Vasen HF, Moslein G, Alonso A, et al. Guidelines for the clinical management of familial adenomatous polyposis (FAP). Gut. 2008;57:704713.

60. Tariq K, Ghias K. Colorectal cancer carcinogenesis: a review of mechanisms. Cancer Biol Med. 2016;13:120-135.

61. Kelley JR, Duggan JM. Gastric cancer epidemiology and risk factors. J Clin Epidemiol. 2003;56:1-9.

62. Bertario L, Russo A, Sala P, et al. Survival of patients with hereditary colorectal cancer: comparison of HNPCC and colorectal cancer in FAP patients with sporadic colorectal cancer. Int J Cancer. 1999;80:183187.

63. Moslein G, Pistorius S, Saeger HD, Schackert HK. Preventive surgery for colon cancer in familial adenomatous polyposis and hereditary nonpolyposis colorectal cancer syndrome. Langenbecks Arch Surg. 2003;388:9-16

64. Vitellaro M, Bonfanti G, Sala P, et al. Laparoscopic colectomy and restorative proctocolectomy for familial adenomatous polyposis. Surg Endosc. 2011;25:1866-1875.

65. Vitellaro M, Ferrari A, Trencheva K, et al. Is laparoscopic surgery an option to support prophylactic colectomy in adolescent patients with Familial Adenomatous Polyposis (FAP)? Pediatr Blood Cancer. 2012:59:1223-1228.

66. Vasen HF, Blanco I, Aktan-Collan K, et al. Revised guidelines for the clinical management of Lynch syndrome (HNPCC): 
recommendations by a group of European experts. Gut. 2013;62:812823.

67. Ferrari A, Schneider DT, Bisogno G. The founding of the European Cooperative Study Group on Pediatric Rare Tumors-EXPeRT. Expert Rev Anticancer Ther. 2013;13(1):1-3.

68. Ferrari A, Schneider DT, Bisogno G, et al. The challenge of very rare childhood cancer in developed and developing countries. Expert Opinion on Orphan Drugs. 2017 http://dx.doi.org/10.1080/21678707.2017. 1298440

\section{SUPPORTING INFORMATION}

Additional Supporting Information may be found online in the supporting information tab for this article.

How to cite this article: Indini A, Bisogno G, Cecchetto G, et al. Gastrointestinal tract carcinoma in pediatric and adolescent age: The Italian TREP Project experience. Pediatr Blood Cancer. 2017;64:e26658. https://doi.org/10.1002/pbc.26658 